\title{
KOMPARASI STRATEGI INVESTASI AKTIF DAN PASIF UNTUK OPTIMALKAN RETURN SAHAM YANG TERDAFTAR DI BURSA EFEK INDNESIA
}

\author{
Venus Kusumawardana \\ PT Reliance Securities Cabang Malang \\ E-mail:venuskusuma@yahoo.com
}

\begin{abstract}
The purpose of this study was to test an active strategy (moving leverage) with a passive strategy (buy, sell and hold strategy) to determine which strategy to generate optimal returns with to compair of all strategy. Method by collecting data is then processed and analyzed using software ChartNexus. An indicators moving everage 5, 10, 30, bollingerband and compare the return of an active strategy with passive strategies. The results of this research note that suitable and appropriate technical analysis to forecast stock prices to determine buy, sell and hold, to optimize stock returns and shows that an active strategy is able to out perform a passive strategy when the market is bearish and volatile. The use of passive strategies can provide superior results, when used on a very bullish market conditions. Volatile market conditions that are more suitable to use the strategy of comparison between the strategies of active and passive strategies.
\end{abstract}

Keywords: Technical Analysis, Moving Averages, Strategy Active \& Passive, Return.

\begin{abstract}
Abstrak
Penelitian ini bertujuan menguji strategi aktif (moving everage) dengan strategi pasif (buy, sell and hold strategy) untuk menentukan strategi mana yang menghasilkan return optimal atau dengan mengkomparasikan strategi keduanya. Metode pengumpulan data kemudian diolah dan dianalisis menggunakan sofware ChartNexus. Indikator menggunakan moving everage 5, 10, 30, bollingerband dan membandingkan return dari strategi aktif dengan strategi pasif. Hasil penelitian diketahui bahwa analisis teknikal cocok dan tepat untuk meramalkan harga saham guna menentukan buy, sell and hold, untuk optimalkan return saham serta menunjukkan bahwa strategi aktif mampu mengungguli strategi pasif ketika pasar sedang dan fluktuatif. Penggunaan strategi pasif dapat memberikan hasil lebih unggul, bila digunakan pada kondisi pasar yang sedang bearish. Kondisi pasar yang sedang volatile lebih cocok menggunakan strategi komparasi antara strategi aktif dan strategi pasif.
\end{abstract}

Kata Kunci : Analisis Teknikal, Moving everage, Strategi Aktif \& Pasif, Return. 
Faktor yang di pertimbangkan investor berinvestasi saham yaitu ada dua return dan risk. Investor menyukai return tinggi tapi tidak menyukai risk tinggi. Semakin besar return maka risk semakin besar pula. Untuk memperoleh return yang optimal, Investor harus jeli memilih saham yang prospek tumbuh kedepan melihat momentum kapan saat buy, sell, atau hold. Menentukan strategi investasi menentukan keberhasilan optimalkan return dan mengurangi risk. Return hasil diperoleh dari investasi, return dapat berupa return realisasi yang sudah terjadi atau return ekspektasi yang belum terjadi. Return total terdiri dari capital gain (loss) dan yield. Capital gain (loss) yaitu selisih harga jual dikurangi harga beli.

Untuk minimalkan risk dengan menggunakan strategi investasi. Menurut Tandelilin (2001:199), Strategi investasi umumnya ada dua macam, yaitu active strategy dan passive strategy. Active strategy Merupakan tindakan investor secara aktif dalam melakukan pemilihan beli dan jual saham, mencari informasi, mengikuti waktu dan pergerakan harga saham guna mendapatkan return. Tujuan strategi aktif ini adalah mendapatkan return portofolio saham yang melebihi return portofolio saham yang diperoleh dari strategi pasif. Grossman dan Stiglitz (1980) mengatakan bahwa investasi aktif mendapatkan return lebih baik dari Strategi Pasif (passive strategy).

Strategi Pasif (passive strategy) merupakan tindakan investor yang cenderung pasif dalam berinvestasi saham di pasar modal dan hanya mendasarkan pergerakan sahamnya pada pergerakan indeks pasar. Tujuan dari strategi pasif ini adalah memperoleh return portofolio sebesar indeks pasar dengan menekankan seminimal mungkin risiko dan biaya investasi yang harus dikeluarkan (Jones, 2004). Untuk memprediksikan perubahan harga saham tersebut, maka diperlukan analisis saham. Terdapat dua pendekatan yang sering dilakukan untuk menganalisis harga saham, yaitu analisis fundamental dan analisis teknikal (Sharpe dkk, 1997).

Komponen Return Saham Menurut Tandelilin (2001: 48), return saham terdiri dari dua komponen, yaitu: a. Capital gain (loss) yaitu kenaikan (penurunan) harga suatu saham yang bisa memberikan keuntungan (kerugian) bagi investor. b. Yield merupakan komponen return yang mencerminkan aliran kas atau pendapatan yang diperoleh secara periodik dari suatu investasi saham.

Rumus perhitungan pengembalian total (Total Return) dan tingkat pengembalian (Rate of Return) sebagai berikut : Secara sistematis, perhitungan return saham adalah sebagai berikut:

Return saham $=\frac{\mathrm{Pt}-\mathrm{Pt}-1+\mathrm{Dt}}{\mathrm{Pt}-1}$

Keterangan $; \mathrm{Pt}=$ harga saham pada periode $\mathrm{t}$; Pt-1 = harga saham pada periode $\mathrm{t}-1 ; \mathrm{Dt}=$ Dividen pada periode t (Jogiyanto, 2009: 201)

William (2006) berpendapat terdapat dua macam strategi yang dapat dilakukan investor dalam pembentukan portofolio, yaitu : strategi aktif (active strategy) dan strategi pasif (passive strategy). Strategi portofolio aktif (active strategy) adalah strategi yang menggunakan informasi dan teknik peramalan untuk mencari kinerja yang lebih baik dari suatu portofolio saham perusahaan tercatat dalam Tandelilin (2001:199). 
Strategi aktif memuat beberapa strategi, yang pertama adalah strategi pemilihan saham dimana investor secara aktif menganalisis dan memilih saham-saham terbaik. Kedua, strategi rotasi sektor yang merupakan strategi untuk melakukan investasi pada sahamsaham perusahaan yang berge-rak pada sektor tertentu. Ketiga, yaitu strategi momentum harga, bahwa waktu-waktu tertentu harga akan terjadi perubahan merefleksikan pertumbuhan perusahaan. investor mencari momentum yang tepat untuk memberikan keuntungan bagi investor melalui tindakan menjual atau membeli saham.

Strategi Pasif (passive strategy), merupakan tindakan investor yang cenderung pasif dalam berinves-tasi saham dan mendasarkan pergera-kan sahamnya pada pergerakan indeks pasar. Strategi pasif adalah strategi membeli dan menahan portofolio dalam jangka panjang (buy and hold). Biasanya saham yang dibeli disebabkan saham tersebut akan mengikuti suatu indeks pasar. Pendekatan investasi ini secara umum disebut indexing. Tujuan dari indexing portofolio adalah bukan mengalahkan indeks yang menjadi acuan tetapi mencocokkan kinerjanya (Tandelilin, 2001:9).

Kegiatan untuik memprediksi perubahan harga saham, maka diperlukan analisis saham. Terdapat dua pendekatan yang sering dilakukan untuk menganalisis harga saham, yaitu analisis fundamental dan analisis teknikal (Sharpe dkk, 1997). Analisis fundamental adalah analisis yang berhubungan dengan fundamental suatu perusahaan, posisi keuangan suatu perusahaan dalam laporan keuangan. Selain itu Analisis fundamental juga melihat kondisi perekonomian dan politik suatu Negara, seperti inflasi, ekonomi makro, ataupun stabilitas Nasional. Analisis fundamental memperkirakan pergerakan di masa yang akan datang dengan melihat laporan keuangan serta kondisi perekonomian suatu Negara. (Husnan;2004).

Analisis teknikal adalah analisis yang memperkirakan pergerakan harga dimasa yang akan datang dengan cara melihat pergerakan harga dimasa lalu. investor juga berasumsi bahwa harga yang tercermin di pasar sudah menunjukan segala faktor yang mempengaruhinya seperti rumor atau isu yang beredar. Salah satu asumsi dalam analisis teknikal adalah history repeat itself yaitu harga saham dimasa lalu dapat digunakan untuk memprediksi harga saham dimasa yang akan datang. Asumsi Market action discount everything yaitu apa yang terjadi pada pergerakan harga, itu sudah menjelaskan semua kejadian yang ada. Serta asumsi terkhir adalah Price move in trend yaitu harga saham bergerak dalam sebuah trend (Ong, E.,2011).

Menurut Lawrence (1997) analisis teknikal harga saham dengan metode moving average memiliki kelemahan sebagai berikut : ketelitian melihat grafik merupakan hal yang sangat penting untuk memanfaatkan signal buy and signal sell, interpretasi dalam melihat pergerakan harga saham/grafik untuk setiap analis berbeda-beda. Kadang-kadang indikator moving average ini juga dapat memberikan signal yang salah. Dari hasil penelitian Ni Putu Santi Suryatini (2007) yang berjudul: " Perbedaan Kinerja Portofolio Berdasarkan Strategi Aktif dan Pasif pada Saham LQ-45 di BEJ dengan hasil penilaian berdasarkan strategi aktif, diperoleh expected return portofolio sebesar $1,7 \%$ dengan resiko sebesar $0,34 \%$. 
Berdasarkan strategi pasif, yaitu mengikuti indeks LQ-45 diperoleh expected return sebesar $1,0 \%$ dengan (risiko) sebesar 0,25\%. Hasil penelitian tersebut lebih unggul strategi aktif sebesar $0,7 \%$ namun resikonya lebih tinggi strategi aktif.

Pada penelitian (Natica, werner, Dedi;2014) dengan judul Investasi: Komparasi: Strategi Buy and hold dengan pendekatan Teknikal. Penelitian tersebut menggunakan sampel LQ45 yang mewakili pasar berkembang dan S\&P 500 yang mewakili pasar maju selama periode 2001-2011. Hasil dari penelitian menunjukkan bahwa analisa teknikal lebih efektif digunakan saat kondisi ekonomi bearish. Sedangkan buy and hold strategy lebih efektif digunakan saat kondisi ekonomi bullish. Hasil yang sama terlihat pada LQ45 maupun S\&P500.

Fernando Fernandez-Rodriquez, Christian Gonzalez-Martel, dan Simon Sosvilla-Rivero (2000), menemukan dalam penelitian mereka di pasar modal Madrid bahwa buy-andhold strategy lebih unggul ketika kondisi pasar bullish. Loddy Li Putra, Werner R. Murhadi dan Putu Anom Mahadwartha (2013), Berdasarkan hasil penelitian rata-rata strategi pasif (buy-and-hold strategy) menghasilkan return yang lebih unggul dibandingkan strategi aktif (moving average). Hal tersebut didukung oleh kondisi pasar modal Indonesia yang sedang bullish. Dapat disimpulkan bahwa penggunaan strategi pasif (buy-and-hold strategy) dapat memberikan hasil yang lebih unggul, bila digunakan pada kondisi pasar yang sedang bullish. Sedangkan, pada kondisi bearish strategi pasif akan memberikan kerugian yang lebih besar

\section{dibanding strategi aktif (moving average).}

Melalui uraian diatas maka penulis akan menguji dan menganalisis dengan menggunakan analisa teknikal menggunakan sofware Chart Nexus. Penelitian ini menguji dan menganalisa penentuan posisi signal kapan lakukan buy, sell dan hold mengetahui strategi investasi aktif dan pasif dapat mengoptimalkan penca-paian return saham. Serta bagaimana jika dikomparasikan keduanya. Peneli-tian ini mengambil objek pene-litian perusahaan IDX 30 periode Januari 2012 s/d Desember 2015 yg terdaftar di BEI.

Tujuan penelitian ini untuk menguji dan menganalisa penentuan posisi signal kapan melakukan buy, sell and hold. Menguji dan mengan-alisa strategi aktif dan strategi pasif juga mengkomparasikan (mengkombinasikan) strategi aktif dan strategi pasif untuk pencapaian return saham yang optimal.

\section{Metode Penelitian}

Metode yang digunakan dalam penelitian ini adalah metode deskriptif kualitatif. Menggunakan return sebagai variabel yang diteliti. Penelitian ini menggunakan jenis data sekunder, yaitu saham yang masuk dalam IDX $30 \mathrm{yg}$ terdaftar di BEI periode 2 Januari 2012 s/d 30 Desember 2015. Pengumpulan data grafik pergerakan harga saham akan diperoleh dari sofware ChartNexus. Harga saham yang digunakan adalah harga penutupan (clossing price). Dengan menentukan titik sinyal buy and sell saham yang akan diobservasi. 
Komparasi Strategi Investasi Aktif...( Venus Kusumawardana)

\section{Hasil Penelitian dan Pembahasan}

Objek penelitian ini adalah perusahaan yang terdaftar di Bursa Efek Indonesia dan masuk dalam daftar indeks IDX 30, terdapat 30 perusahaan dalam daftarnya. Tetapi penulis hanya memilih 10 perusahaan dengan kriteria memiliki kapitalisasi pasar paling tinggi berdasarkan perengkingan, dan yang berbeda dalam bidang industrinya. Daftar 10 perusahaan tersebut pada tabel 1.

Setelah menentukan daftar indeks IDX 30 menjadi 10 nama perusahaan kemudian penulis menganalisa dan menentukan titik sinyal buy dan sell. Menghitung potensi gain dan loss dari masing-masing perusahaan juga persentasenya yang signifikan kenaikan dan penurunannya dengan menggunakan ChartNexus yang di bagi berdasarkan strategi aktif dan strategi pasif pada periode Januari 2012 s/d Desember 2015. Kemudian penulis mendata dan memasukkannya ke tabel. Penulis juga menggambarkan kondisi perusahaan dengan analisa aktif juga pasif dengan gambar chart yang diambil dari ChartNexus.

Penentuan sinyal kapan buy saham, maka perlu memastikan arah market up trend (bullish). Adapun ciriciri beberapa sinyal buy sebagai berikut (1) Saat Market Menembus Garis Resistance Terdekat (Base Line).

Garis resistance dibangun minimal 2 puncak sejajar yang menunjukkan di level tersebut harga dijaga oleh seller. Namun ketika garis resistance berhasil ditembus, posisi seller kalah, maka harga akan terjadi kenaikan. Seperti pada gambar 1.

Saat Grafik Candlestick Bullish Bodynya Semakin Memanjang. Panjang badan candlestick menunjukkan dominasi buyer atau seller. Candlestick bullish dengan badan lebih panjang dari sebelumnya menunjukkan dominasi buyer. Seperti pada gambar 2 .

Berpotongannya Garis Indikator MA5 dan MA10 (Golden Cross). Pada analisa teknikal, ketika garis chart short-term moving average (MA5) me-

Tabel 1. Daftar 10 Saham terpilih dari indeks IDX 30

\begin{tabular}{|c|c|c|c|}
\hline Kode & Nama Perusahaan & Tanggal IPO & $\begin{array}{l}\text { Kapitalisasi Pasar } \\
\text { Per28-Jul-2015 }\end{array}$ \\
\hline UNVR & iilever & 82 & 305.200 .000 .000 .000 \\
\hline TLKM & $\mathrm{T}$ & & 000 \\
\hline ASII & Interı & & .000 \\
\hline BBRI & k Raky & 101 & .000 \\
\hline PGAS & $\begin{array}{l}\text { Perusahaan Gas Negara (Persero) } \\
\text { Tbk }\end{array}$ & 03 & 95.39 \\
\hline GGRM & Gudang Garam Tbk & & 92.30 \\
\hline KLBF & Kalb & & 77.57 \\
\hline INTP & Indocement Tungg & $05 \mathrm{D}$ & 77.029 .773 .301 .575 \\
\hline ICHP & $\begin{array}{l}\text { Indofood CBP Sukses Makmur } \\
\text { Tbk }\end{array}$ & 07 Oktober 2010 & 70.262 .995 .700 .000 \\
\hline UNTR & United Tractor Tbk & 19 September 1989 & 66.955 .925 .691 .200 \\
\hline
\end{tabular}

Sumber: Data diolah 
Ekonomika-Bisnis,Vol. 7 No. 1 Bulan Januari Tahun 2016 Hal 41-54

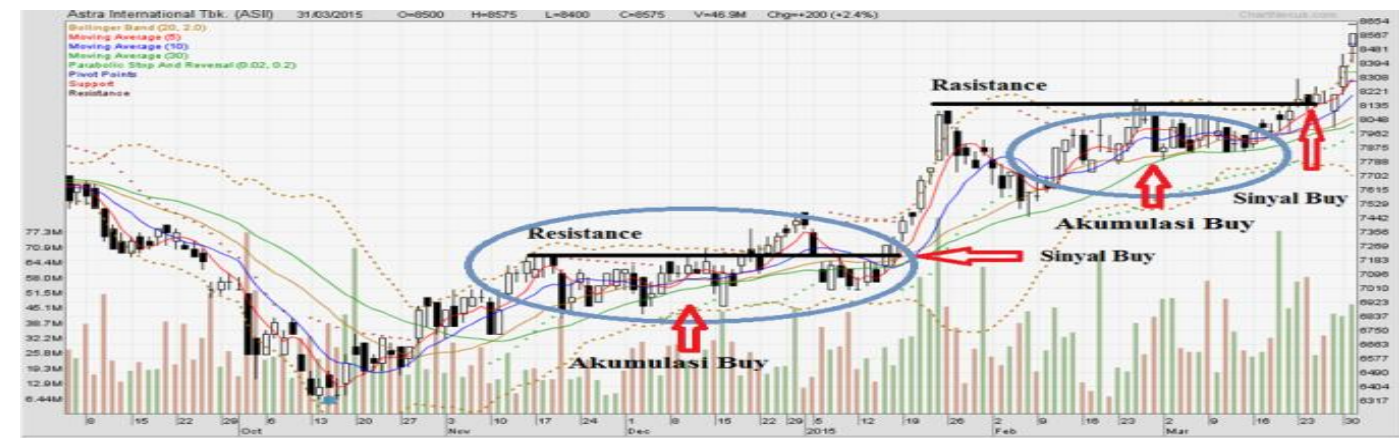

Sumber : ChartNexus

Gambar 1. Sinyal Buy Saat Menembus Garis Resistance

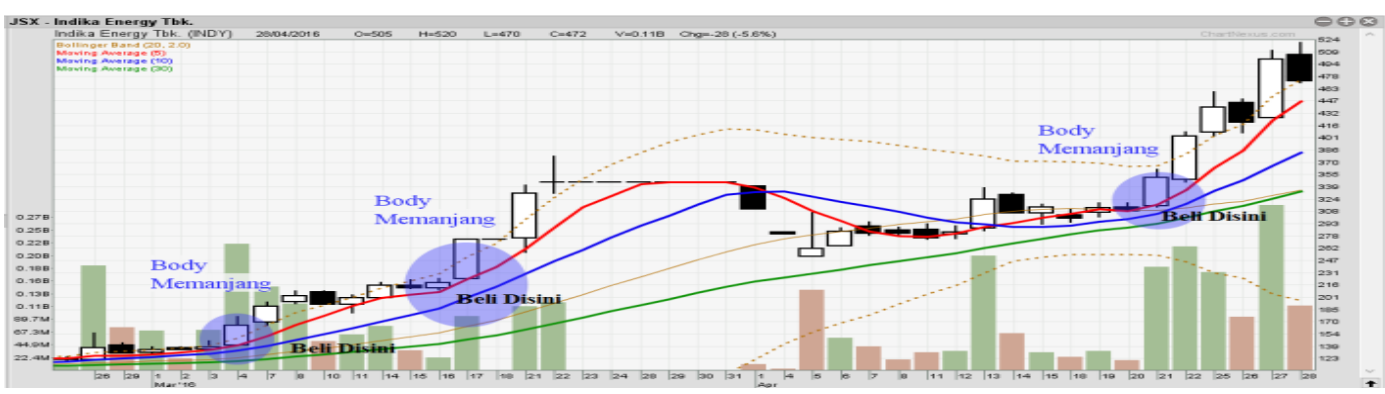

Sumber : ChartNexus

Gambar 2. Candlestick Bullish Body Chart-nya Semakin Memanja

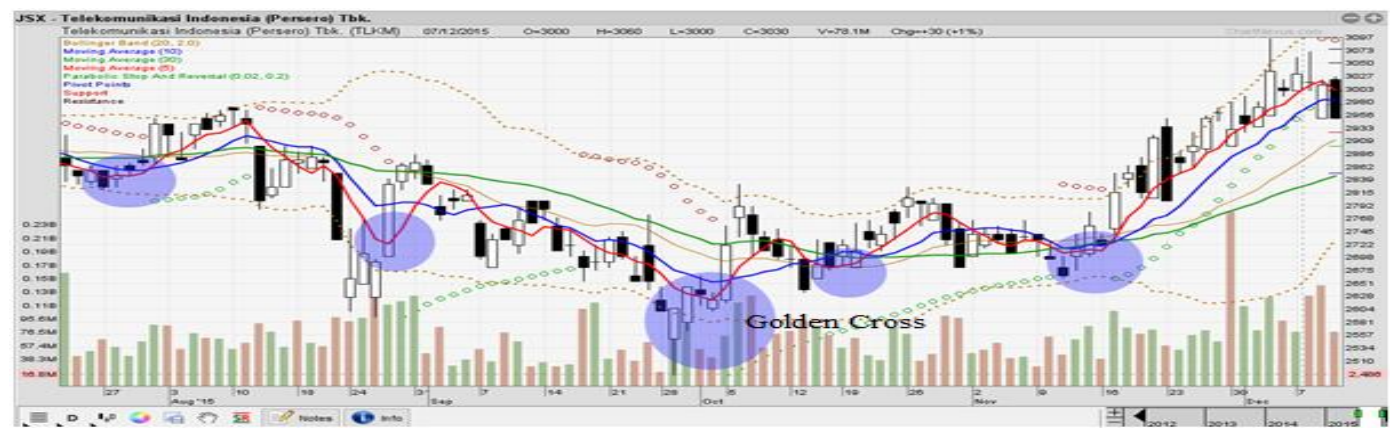

Sumber : ChartNexus

Gambar 3. Titik Indikator Golden Cros

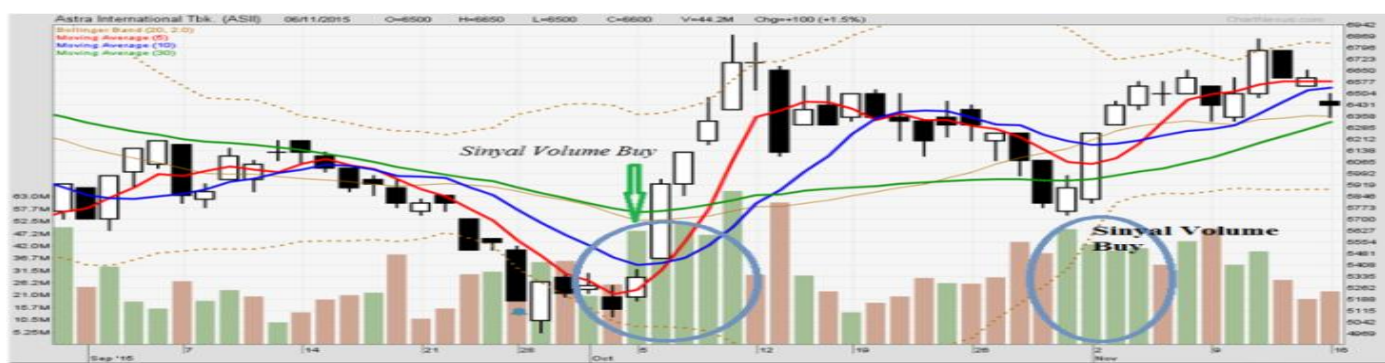

Sumber : ChartNexus

Gambar 4. Sinyal Volume Buy 
motong long-term moving average (10 \& 30) dari bawah ke atas chart di sebut Golden Cross, maka harga saham akan naik, mengindikasikan posisinya oversold (jenuh jual) menunjukkan sinyal beli. Seperti gambar 3 .
Sinyal Buy terjadi saat Volume Buy Meningkat. Volume menunjukkan jumlah transaksi pada periode tertentu, kekuatan minat jual dan beli, mengkonfirmasi pergerakan harga saham. Sinyal up trend (trend bullish) terlihat pada volume buy yang signifikan. Seperti pada gambar 4 .

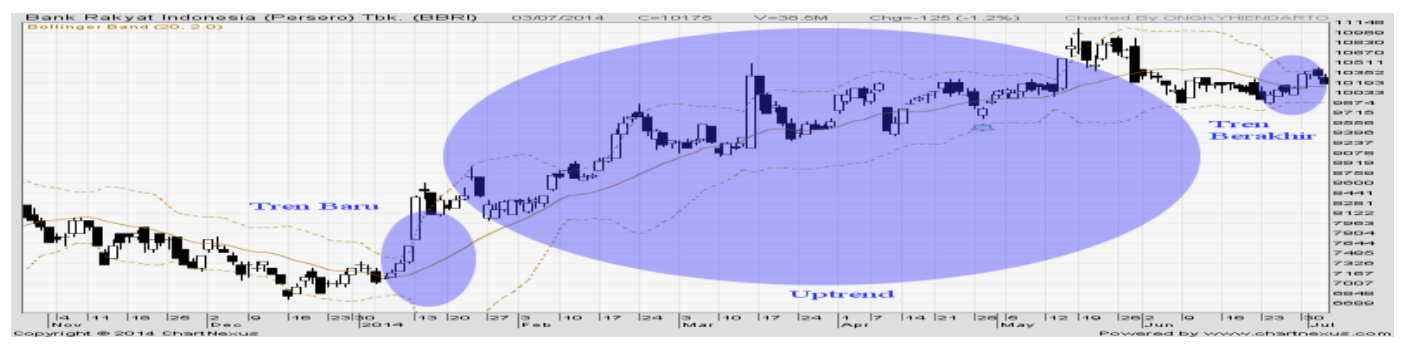

Sumber : ChartNexus

Gambar 5. Bollinger Band Trend Up

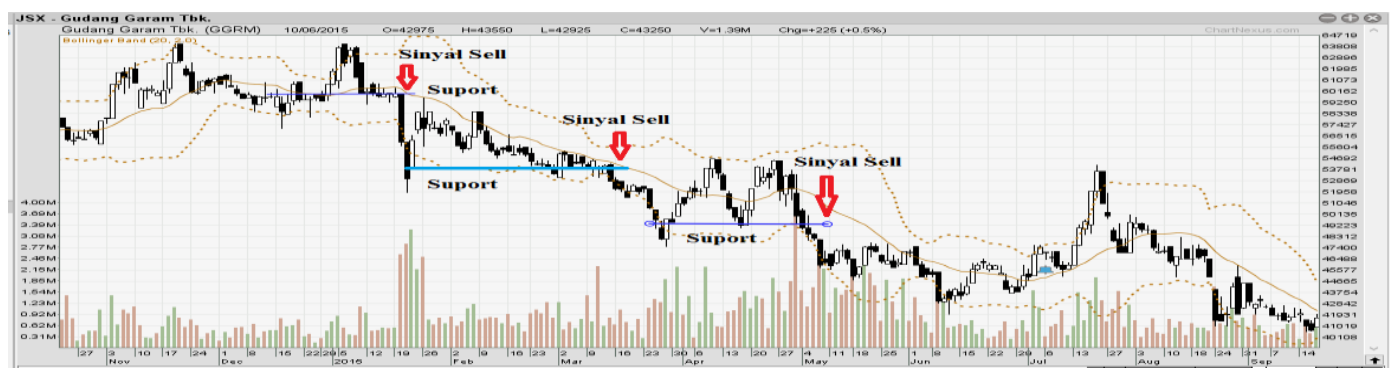

Sumber : ChartNexus

Gambar 6. Body Candle Semakin Mengecil

Sinyal Up Trend Sebagai Sinyal Buy. Sinyal up trend terjadi saat candlestick chart menembus bollinger band tengah dari bawah ke atas, dan chart selalu diatas garis bollinger band tengah. Seperti pada gambar 5 .

Untuk menentukan indikator kapan melakukan penjualan saham (sell) maka kita harus memastikan dulu bahwa arah market akan turun (douwn trend) dengan ciri-ciri sebagai berikut (1) Saat Market Menembus Garis Suport Terdekat (Base Line).

Garis suport dibangun minimal 2 lembah sejajar yang menunjukkan di level tersebut harga dijaga oleh buyer.
Namun ketika garis suport berhasil ditembus, posisi buyer kalah, maka harga akan terjadi penurunan. Seperti pada gambar 6 .

Saat Grafik Candlestick Bearish Bodynya Semakin Memanjang Panjang badan candlestick menunjukkan dominasi buyer atau seller. Candlestick Bearish dengan badan lebih panjang dari sebelumnya menunjukkan dominasi seller. Seperti pada gambar 7 .

Berpotongannya Garis Indikator MA 5 dengan MA 10 (Dead Cross). Pada analisa teknikal, ketika garis chart short-term moving average (MA5) memotong long-term moving average 
(10 \& 30) dari atas ke bawah chart di- akan turun, mengindikasikan posisinya sebut dead cross, maka harga saham Overbought (jenuh beli) menunjukkan sinyal jual. Seperti gambar 8 .

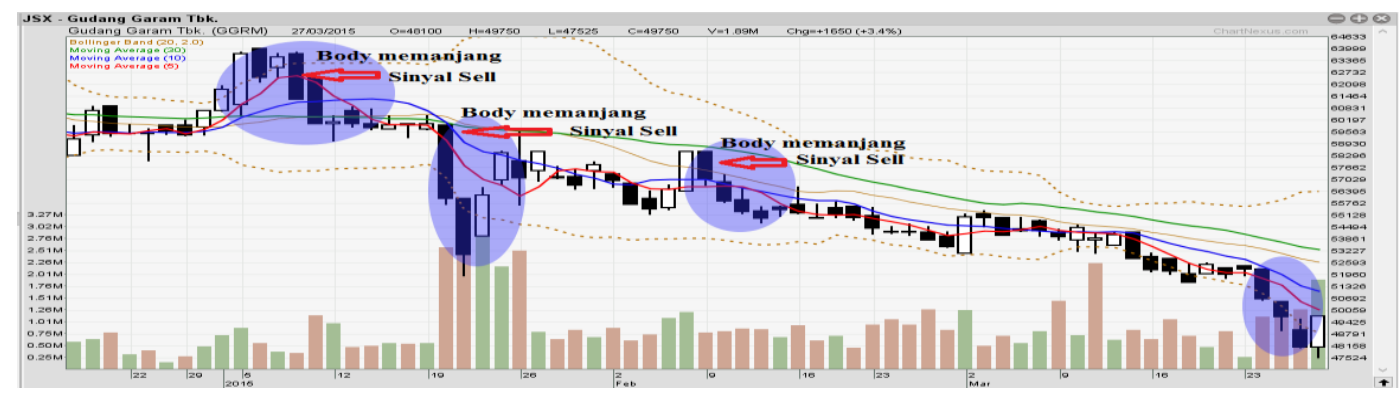

Sumber : ChartNexus

Gambar 7. Candlestick Bearish Body

Chart-nya Semakin Memanjang

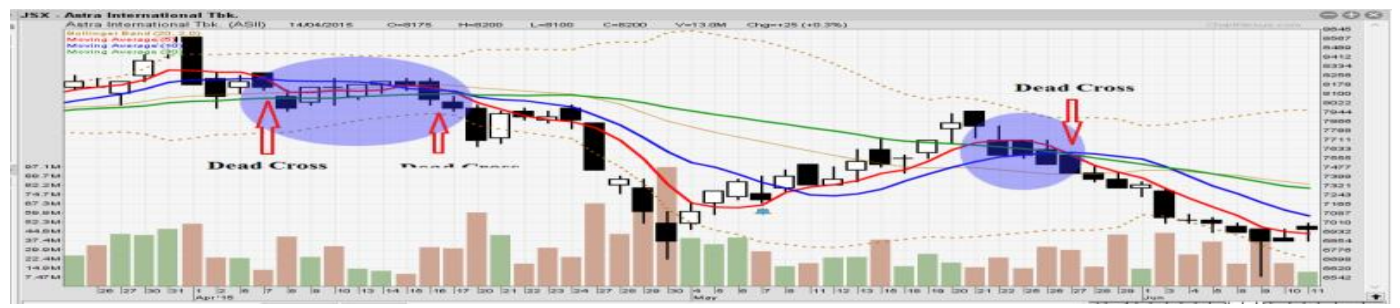

Sumber : ChartNexus

Gambar 8. Titik Indikator Dead Cross

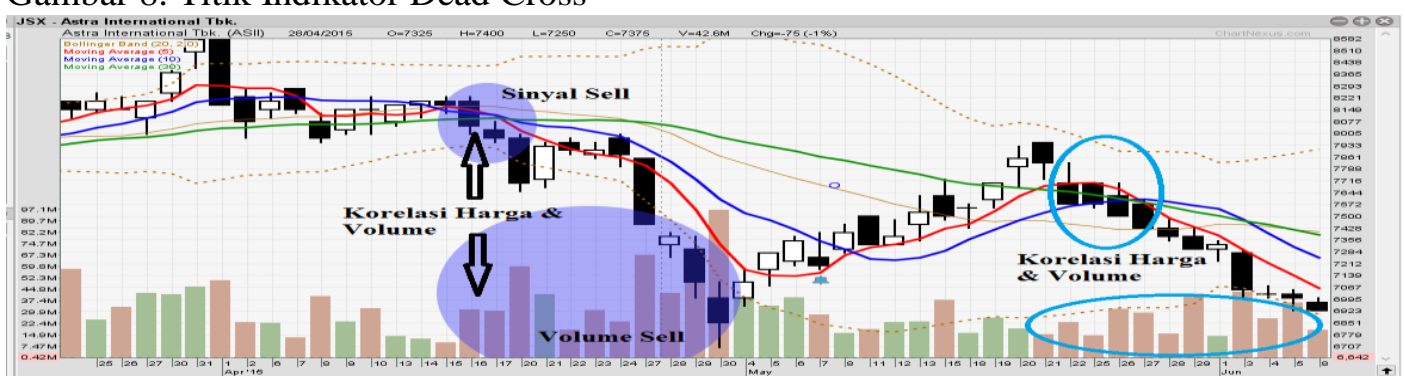

Sumber : ChartNexus

Gambar 9. Sinyal Volume Sell

Sinyal Sell terjadi saat Volume Buy Meningkat. Volume menunjukkan jumlah transaksi pada periode tertentu, kekuatan minat jual dan beli, mengkonfirmasi pergerakan harga saham. Sinyal douwn trend (trend bearish) terlihat pada volume sell yang signifikan. Seperti pada gambar 9.

Sinyal Douwn Trend sebagai sinyal Buy. Sinyal douwn trend terjadi saat candlestick chart menembus bolli- nger band tengah dari atas ke bawah, dan chart selalu dibawah garis bollinger band tengah. Seperti pada gambar 10 .

Untuk menghasilkan return saham otimal, investor dapat mengkomparasikan strategi aktif dan pasif. Yaitu buy saat signal buy terjadi, hold dan sell saat signal sell terjadi. Menunggu hingga harga kembali turun dan buy saat signal buy kembali dengan melihat beberapa indikator seperti yang dijelaskan diatas. Seperti pada gambar 11. 


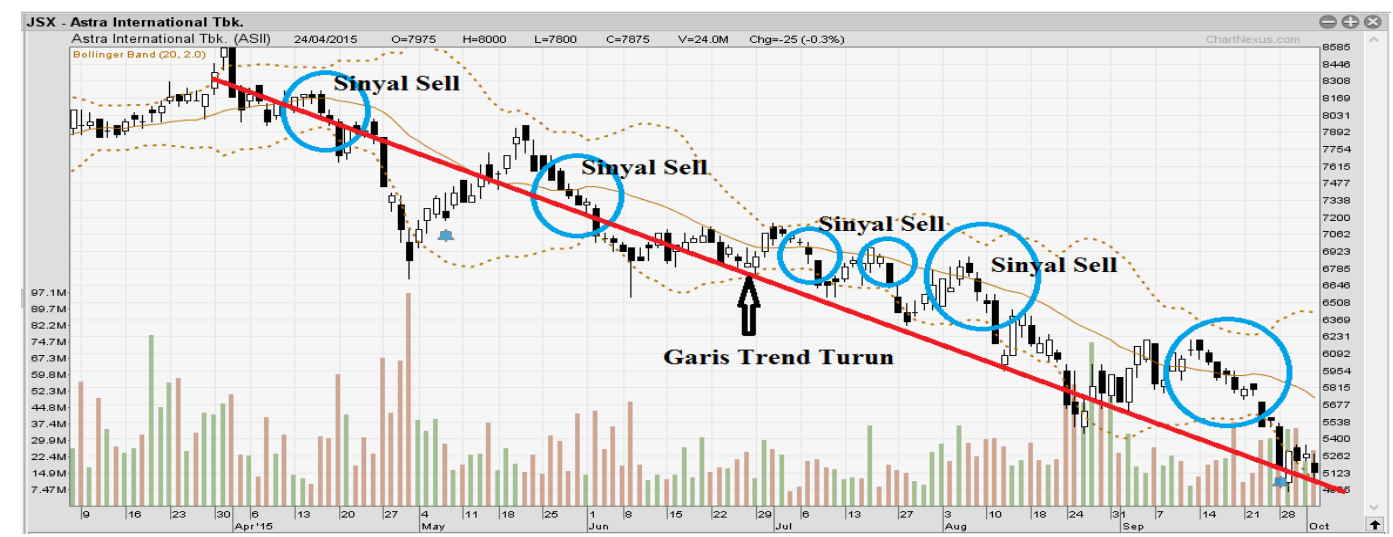

Sumber : ChartNexus

Gambar 10. Bollinger Band: Trend Up

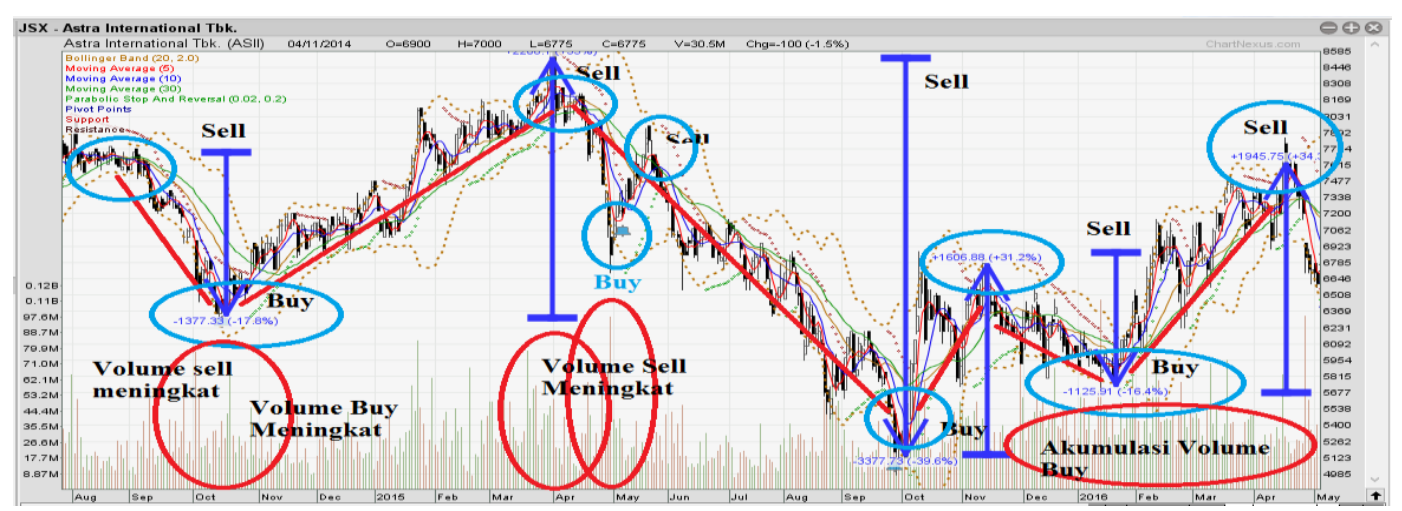

Sumber : ChartNexus

Gambar 11. Penentuan Komparasi Sinyal Buy and Sell

Hasil Perhitungan Gain dan Loss Penggabungan 10 Emiten Strategi Pasif Periode Jan 2012 s/d Des 2015 dapat dijabarkan dalam tabel 2. Pada tabel 2 menggambarkan peng-gabungan data perhitungan gain dan loss 10 emiten strategi pasif periode 2 Jan 2012 s/d 7 Des 2015, terdapat 6 emiten pada posisi gain yaitu : UNVR, TLKM, BBRI, KLBF, INTP, serta ICBP dan 4 emiten posisi loss yaitu : ASII, PGAS, GGRM serta UNTR. Demikain terdapat 6 emite yang positif prosentasenya dan terdapat 4 emiten posisi minus prosentasenya

Berdasarkan tabel 2 di atas menunjukkan gain tertinggi diperoleh UNVR sejumlah Rp 16.937 atau $(91,80$
$\%$ ). Demikian KLBF meskipun mendapatkan gain sebesar Rp 591,82 (86,90 $\%)$.

Pada tabel 3 menggambarkan penggabungan data hasil perhitungan gain dan loss pada 10 emiten strategi aktif periode Januari 2012 s/d Desember 2015. Posisi gain GGRM tertinggi memberikan return sejumlah Rp 160.593 (361,70 \%), Sedangkan return terendah yaitu KLBF sebesar Rp 4.993 (471,00\%). Posisi loss GGRM tertinggi sejumlah Rp-164.899 ($309,40 \%$ ), Sedangkan loss terendah yaitu KLBF sebesar Rp -5.147,07 ($396,705 \%$ ).

Selanjutnya hasil komparasi perhitungan gain dan loss dengan men- 
Ekonomika-Bisnis,Vol. 7 No. 1 Bulan Januari Tahun 2016 Hal 41-54

\begin{tabular}{lccccc}
\hline \multicolumn{2}{l}{ Tabel 2. Penggabungan 10 Emiten Strategi Pasif } & & & & \\
\hline STOCK & Periode & Gain & Loss & $(+\%)$ & $(-\%)$ \\
\hline UNVR & 2 Januari 2012 S/D 7 Desember 2015 & 16.937 & & $91.80 \%$ & \\
TLKM & 2 Januari 2012 S/D 7 Desember 2015 & $1.694,4$ & & $121.30 \%$ & \\
ASII & 2 Januari 2012 S/D 7 Desember 2015 & & -913.7 & & $-12.40 \%$ \\
BBRI & 2 Januari 2012 S/D 7 Desember 2015 & 438,14 & & $64.80 \%$ & \\
PGAS & 2 Januari 2012 S/D 7 Desember 2015 & & -503.72 & & $-16.30 \%$ \\
GGRM & 2 Januari 2012 S/D 7 Desember 2015 & & -10.994 & & $-17.40 \%$ \\
KLBF & 2 Januari 2012 S/D 7 Desember 2015 & 591,82 & & $86.90 \%$ & \\
INTP & 2 Januari 2012 S/D 7 Desember 2015 & $2.540,57$ & & $14.30 \%$ & \\
ICHP & 2 Januari 2012 S/D 7 Desember 2015 & $4.387,14$ & & $64.80 \%$ & \\
UNTR & 2 Januari 2012 S/D 7 Desember 2015 & & -11.353 & & $-43,40 \%$ \\
\hline
\end{tabular}

Sumber: Data diolah

Tabel 3. Penggabungan 10 Emiten Strategi Aktif

\begin{tabular}{|c|c|c|c|c|c|}
\hline $\mathrm{K}$ & Periode & Gain & Loss & $(+\%)$ & $(-\%)$ \\
\hline UNVR & 2 Januari 2012 S/D 7 Desember 2015 & 106.323 & .5 & $361,20 \%$ & $-265,40 \%$ \\
\hline LKM & Januari 2012 S/D 7 Desember 2015 & $6.868,12$ & & $328,60 \%$ & $-180,70 \%$ \\
\hline ASII & 015 & & -17.278 & $282,50 \%$ & $-241,40 \%$ \\
\hline BBRI & S/D 7 & 35.5 & $\begin{array}{c}- \\
25.660,4\end{array}$ & $452,40 \%$ & $-272,90 \%$ \\
\hline & & & -13 . & & -300 \\
\hline GR & 115 & 160 & -164.89 & $0 \%$ & $-309,40 \%$ \\
\hline KLBF & 015 & 4.9 & -5.147 & 471 & $\begin{array}{c}- \\
396,705 \%\end{array}$ \\
\hline INT & 2 Januari 2012 S/D 7 Desember 2015 & $87.915,4$ & $80.575,9$ & $\%$ & $-397,70 \%$ \\
\hline ICHP & 2 Januari 2012 S/D & $35.902,84$ & $\begin{array}{c}- \\
27.620,6\end{array}$ & $408,43 \%$ & $-262,10 \%$ \\
\hline UNTR & 2 Januari 2012 S/D 7 Desember 2015 & $79.511,64$ & -92.578 & $433,30 \%$ & $-406,40 \%$ \\
\hline
\end{tabular}

Sumber: Data diolah

Tabel 4. Komparasi Strategi Pasif \& Aktif 10 Emiten Periode 2012 s/d 2015

\begin{tabular}{lccc}
\hline \multicolumn{1}{c}{ STOCK } & Periode & Gain/ Loss & (+-\%) \\
\hline UNVR & 2 Januari 2012 S/D 7 Desember 2015 & $194.876,18$ & $626.60 \%$ \\
TLKM & 2 Januari 2012 S/D 7 Desember 2015 & 12.212 .22 & $508.60 \%$ \\
ASII & 2 Januari 2012 S/D 7 Desember 2015 & $334.964,49$ & $523.90 \%$ \\
BBRI & 2 Januari 2012 S/D 7 Desember 2015 & 61.242 .75 & $725.30 \%$ \\
PGAS & 2 Januari 2012 S/D 7 Desember 2015 & 27.712 .3 & $641.30 \%$ \\
GGRM & 2 Januari 2012 S/D 7 Desember 2015 & 325.492 .54 & $671.10 \%$ \\
KLBF & 2 Januari 2012 S/D 7 Desember 2015 & $10.140,4$ & $867.10 \%$ \\
INTP & 2 Januari 2012 S/D 7 Desember 2015 & $168.491,4$ & $857,7 \%$ \\
ICHP & 2 Januari 2012 S/D 7 Desember 2015 & $63.523,45$ & $670,53 \%$ \\
UNTR & 2 Januari 2012 S/D 7 Desember 2015 & $172.090,58$ & $937,70 \%$ \\
\hline
\end{tabular}

Sumber: Data diolah 
Komparasi Strategi Investasi Aktif...( Venus Kusumawardana)

Tabel 5. Perbandingan Strategi Pasif \& Aktif 10 Emiten Periode 2012 s/d 2015

\begin{tabular}{lcccc}
\hline STOCK & Periode & Selisih $(+/-)$ & $(\%)$ & Pasif/Aktif \\
\hline UNVR & 2 Januari 2012 S/D 7 Desember 2015 & $194.859,245$ & $534.80 \%$ & Aktif \\
TLKM & 2 Januari 2012 S/D 7 Desember 2015 & $10.517,82$ & $387.30 \%$ & Aktif \\
ASII & 2 Januari 2012 S/D 7 Desember 2015 & 34.050 .71 & $511.50 \%$ & Aktif \\
BBRI & 2 Januari 2012 S/D 7 Desember 2015 & $56.855,61$ & $660.50 \%$ & Aktif \\
PGAS & 2 Januari 2012 S/D 7 Desember 2015 & 27.208 .58 & $625.00 \%$ & Aktif \\
GGRM & 2 Januari 2012 S/D 7 Desember 2015 & 314.498 .54 & $653,70 \%$ & Aktif \\
KLBF & 2 Januari 2012 S/D 7 Desember 2015 & 9.548 .68 & $780,80 \%$ & Aktif \\
INTP & 2 Januari 2012 S/D 7 Desember 2015 & $165.950,83$ & $843,4 \%$ & Aktif \\
ICHP & 2 Januari 2012 S/D 7 Desember 2015 & 59.136 .31 & $605.73 \%$ & Aktif \\
UNTR & 2 Januari 2012 S/D 7 Desember 2015 & 160.737 .00 & $894.30 \%$ & Aktif \\
\hline
\end{tabular}

Sumber : Data diolah

Tabel 6 Jumlah Titik Sinyal Up dan Douwn Strategi Aktif 10 Emiten

\begin{tabular}{lcccc}
\hline STOCK & \multicolumn{1}{c}{ Periode } & Gain & Loss & Total \\
\hline UNVR & 2 Januari 2012 S/D 7 Desember 2015 & 26 & 52 & 52 \\
TLKM & 2 Januari 2012 S/D 7 Desember 2015 & 23 & 45 & 45 \\
ASII & 2 Januari 2012 S/D 7 Desember 2015 & 18 & 32 & 32 \\
BBRI & 2 Januari 2012 S/D 7 Desember 2015 & 22 & 39 & 39 \\
PGAS & 2 Januari 2012 S/D 7 Desember 2015 & 20 & 42 & 42 \\
GGRM & 2 Januari 2012 S/D 7 Desember 2015 & 18 & 36 & 36 \\
KLBF & 2 Januari 2012 S/D 7 Desember 2015 & 22 & 45 & 45 \\
INTP & 2 Januari 2012 S/D 7 Desember 2015 & 29 & 57 & 57 \\
ICHP & 2 Januari 2012 S/D 7 Desember 2015 & 25 & 50 & 50 \\
UNTR & 2 Januari 2012 S/D 7 Desember 2015 & 30 & 59 & 59 \\
\hline
\end{tabular}

Sumber : Data diolah

jumlahkan keduanya sehingga menghasilkan gain tinggi. Perhitungan loss menjadi gain karena sebelum terjadi dead cross, investor lakukan sell dan saat sebelum terjadi golden cross investor lakukan buy. Selisih sell ke buy menjadi gain. Gain tertinggi diperoleh GGRM memberikan return $\mathrm{Rp}$ 325.492.54 (671.10\%), akan tetapi dariKLBF memberikan return terkecil Rp10.140,5 867.79\%. Hal ini dapat dilihat di tabel 4.

Jika bandingkan hasil perhitungan strategi aktif dan pasif menunjukkan strategi aktif lebih tinggi return yang diperoleh dibandingkan strategi pasif, seperti di gambarkan pada tabel 5. untuk minimalkan loss (resk).

Pada tabel 6 menggambarkan penggabungan data jumlah titik sinyal Up dan Douwn strategi aktif 10 emiten periode Januari 2012 s/d Desember 2015.

\section{Penutup}

Penulis dapat menyimpulkan dari hasil observasi yang di lakukan, dapat disimpulkan bahwa: pertama, berdasarkan analisa secara teknikal untuk menentukan sinyal indikator kapan buy dalam chart saham, yaitu saat market menembus garis resistance terdekat (base line), saat grafik 
Ekonomika-Bisnis,Vol. 7 No. 1 Bulan Januari Tahun 2016 Hal 41-54

candlestick bullish bodynya semakin memanjang, berpotongannya garis indikator MA 5 dengan MA 10 (golden cross), sinyal buy terjadi saat volume buy meningkat, sinyal up trend sebagai sinyal buy.

Kedua, berdasarkan analisa secara teknikal untuk menentukan sinyal indikator kapan sell dalam chart saham, yaitu saat market menembus garis suport terdekat (base line), saat grafik candlestick bullish bodynya semakin memanjang, berpo-tongannya garis indikator MA 5 dengan MA 10 (dead cross), sinyal sell terjadi saat volume sell meningkat, sinyal down trend sebagai sinyal sell sejajar di bollinger band tengah. Disebut konsolidasi harga saham. Artinya investor dapat menahan.

Ketiga, untuk menentukan sinyal hold, yaitu saat chart berada sahamnya hingga sinyal up atau douwn. Jika naik buy, jika turun sell (cut loss) untuk minimalkan loss (resk). Keempat, strategi pasif (buy-and-hold strategy) menghasilkan return lebih unggul, pada kondisi pasar bullish.

Kelima, pada kondisi bearish strategi pasif akan memberikan kerugian yang lebih besar dibanding strategi aktif (moving average).

Keenam, strategi aktif (moving average) menghasilkan return lebih unggul, saat kondisi pasar bearish. Ketujuh, pada kondisi pasar volatile lebih tepat menggunakan strategi komparasi antara strategi aktif (moving average) dan strategi pasif (buy-andhold strategy).

\section{DAFTAR PUSTAKA}

Brigham, Eugene F and Joel F.Houston. 2006. Dasar-Dasar Manajemen Keuangan, alih bahasa Ali Akbar
Yulianto, Buku satu, Edisi sepuluh. PT. Salemba Empat. Jakarta.

Darmadji, Fakhrudin. 2006. Pasar Modal di Indonesia Pendekatan Tanya Jawab. Salemba Empat. Jakarta.

Eko. 2008. Analisis dan Penilaian Kinerja Portfolio Optimal SahamSaham LQ-45, Jurnal Ilmu Administrasi dan Organisasi, Sept-Des 2008: 178-187

Fernandez-Rodriguez dkk, GonzalesMartel,C,and Sosvilla-rivero,S. 2000. Tecnical Analisis in foreign exchange market: Linier nonlinier trading rules. Fundacion de Estudios Econimia Aplicada Workhing Paper, September 2000

Fabozzi, Frank J dan H. M. Markowitz (Eds). 2002. The Theory And Practice Of Investment Management. United State Of America: John Willey And Sons Inc.

Grossman, S. J. and Stiglitz, J. E. 1980. "On the Impos sibility of Informationally Efficient Markets.The American Economic Review, Vol. 70, No. 3, (June 1980), pp. 393-408.

Husnan, Suad. 2004. Dasar-dasar Teori Portofolio dan Analisis Sekuritas. UPP AMP YKPI. Yogyakarta.

Jones, Charles P. 2004. Investment Analysis and Management. Ed New York: John Wiley and Sons 
Komparasi Strategi Investasi Aktif...( Venus Kusumawardana)

Jogiyanto, H.M. 2010. Teori Portofolio

dan Analisis Investasi. Edisi

Ketujuh. BPFE. Yogyakarta.

Natica Ardani, Werner R.M, Deddi Marciano. 2012. Investasi :

Komparasi Strategi Buy and Hold dengan Pendekatan Teknikal, Jurnal Akuntansi dan Keuangan Vol. 14, No. 1, Mei 2012:32-44

Ong, E. 2011. Technical Analysis for Mega Profit, 7th edition. PT Gramedia Pustaka Utama.

Reilly, Frank K. and Keith, C Brown. 2000. Investment Analysis and Portofolio Management. Florida: The Dryden Press.

Suad Husnan. 2003. Dasar-dasar Teori Portofolio dan Analisis Sekuritas, UPP AMP YKPN.

Umani, M.A. 2012. Impact of Managerial Factors on Commercial Bank Profitabiity: Empirical Evidence From Jordan. International Journal of Academic Research in Accounting, Finance and Management Sciences, Vol.3, No.3, hlm 298310. 
Ekonomika-Bisnis,Vol. 7 No. 1 Bulan Januari Tahun 2016 Hal 41-54 